with the Ghulfan, Gulud, Temein, Keiga, and Liguri peoples. Many tape recordings and photographs were taken and specimens of Nyimang culture collected for the Museum für Völkerkunde.

\title{
Field Researches in Tanganyika
}

Dr. Edward H. Winter, Associate Professor of Anthropology at the University of Illinois, and Mr. Thomas Beidelman of the same university are carrying out field work among the Kaguru of east central Tanganyika. This project is under the auspices of the Ford Foundation's Study of Cultural Regularities, directed by Professor Julian Steward.

\section{Bibliography on North and North-east Africa}

THis bibliography on North and North-east Africa, published by the Library of Congress and compiled by Helen F. Conover, completes the survey of writings on Africa, of which the first part-Africa South of the Sahara-was published in June 1957. The two lists are supplementary to the Library of Congress publication of 1952, Introduction to Africa, but the range of works cited has been extended to include those of scholarly as well as of more general interest. The emphasis is on social, economic, and political aspects of the current scene; history and culture are touched upon, but technological and scientific material, particularly with respect to the physical sciences, is excluded. The aim has been to interpret major facts and issues of each country through annotated references to books, pamphlets, or substantial periodical articles. Preference has been given to writings in English, though for North Africa it has been necessary to rely mainly upon French and Spanish studies. No attempt has been made to deal with source material in Arabic. As in Africa South of the Sahara, entries are annotated to indicate material on the same or closely related themes, so that over 200 works receive comment in addition to the 349 numbered entries in the bibliography. Fifteen political areas ate covered and there is an index of authors.

\section{Guide to Resources for Commonwealth Studies}

THe Guide to Resources for Commonnealth Studies in London, Oxford and Cambridge has been compiled by A. R. Hewitt, the Secretary and Librarian of the Institute of Commonwealth Studies. Its purpose, as set out in the Foreword, is ' to assist advanced research workers, particularly those who have come to Great Britain from overseas, to locate material for the study of the British Commonwealth '. The materials listed fall mainly, but not exclusively, within the fields of history and the social sciences and are limited to libraries and other institutions in London, Oxford, and Cambridge, though it is hoped that the scope may be extended if a further edition is called for. There is a general bibliography, indicating also where detailed bibliographies may be found, and a comprehensive index. The Guide is divided into three parts : Part I is a general survey of resources, listing specialist and other libraries, public archives, parliamentary and official papers, periodicals and newspapers, bibliographies and works of reference. Part II lists individual collections in London, Oxford, and Cambridge. Part III indicates universities in the United Kingdom offering facilities for Commonwealth studies, and gives a list of institutions and organizations concerned with various aspects of Commonwealth affairs.

Among the sources for African studies are the Public Record Office, the Colonial Office, and the Foreign Office; the last was responsible over a period of years for the administration of most of the African territories and its archives contain much material on British interests in Africa before $x 885$ in the Slave Trade Series of Papers (F.O. 84). Institutions containing papers relating specifically to Africa are listed on pp. I4-I 5 ; lists of periodicals p. 44 ; library resources pp. 5 I- $\{3$. Many of the institutions, libraries, and missionary societies listed on pP. 93-179 contain material relevant to African studies. 
The Guide is published by the Athlone Press, University of London, for the Institute of Commonwealth Studies, and costs 21 s.

\section{New Alphabetic Confusions in Africa}

IN an article, 'Comment écrire les langues africaines? Nécessité d'un humanisme africain', M. Houis begins by stressing the necessity for Africans to study their own languages and cultures and thus preserve an African 'humanism'. Up till now, he says, African publications in A.E.F. and A.O.F. have had no wide appeal, because their lack of culture policy prevented them from being integrated into a long-term programme of humanism. From this we reach the conclusion that no writing is possible without a proper alphabet, and he goes on to compare what he calls the 'English system' (which appears to be his name for the 'Africa' alphabet) with the French alphabetic system.

He turns down the former, because it imposes on students certain graphic habits different from the notations they are used to from their primary classes; also certain official habits, but none the less general, are already in use in French territories, and it is important to make a 'pratique' of these habits. Elsewhere he tells us that the 'English system' has served its professed purpose in the framework of British imperial cultural policy (such as teaching children to read and write in the mother tongue before proceeding to English for their real cultural studies); but were it to be introduced into the French sphere, it would encounter, besides a number of practical obstacles, certain criticisms, the main one being the impossibility for the system to ensure a genuine humanistic development within the scope of the policy that has apparently inspired it. (Evidently we are to conclude that no present Hausa literature is humanistic.)

The French system as it stands he also turns down because of its etymological heritage, which would have no meaning in languages with a mere oral tradition. It can, however, be modified and systematized according to the principle of confining oneself to the Latin alphabet (' new letters' too are rejected for the sake of universality and simplicity), and relegating one phoneme to one letter or group of letters.

The alphabet which finally emerges and which has apparently had a favourable reception in French circles, is thus a simplified French alphabet, with an all-Latin list of symbols plus three diacritics (one quite new !); its phonetic interpretation differs from that of the 'Africa' alphabet in the following aspects.

' $e$ ' and ' $O$ ' represent close varieties of ' $e$ ' and ' $O$ ' (it is admitted that this may interfere with tone marking where ' $e$ ' is concerned);

' $\propto$ ' is a central vowel;

(One is glad to notice that M. Houis proposes ' $u$ ' and ' $\ddot{u}$ ' for French ' ou' and ' $u$ '.) 'in " én" 'en' " an ' on' 'on' "un' are all nasalized vowels. (No clue is given here as to how to spell words ending with consonant ' $n$ ' though elsewhere M. Houis has recommended ' $n$ e' and ' $\mathrm{nn}$ ' according as the sound is final or pre-consonantal in a word.)

' $c h$ ' and ' $j$ ' are to be pronounced as in 'chapeau' and ' jeu';

' $t c h$ ' and ' $d j$ ' represent the corresponding affricates;

'gn' as in 'épargne';

' $\mathrm{ng}$ ' as in English 'long' (no clue for the sounds in 'longer');

' $\mathrm{kh}$ ' and ' $\mathrm{gh}$ ' represent velar fricatives (' $\mathrm{x}$ ' is not used at all);

' $r$ ' represents the uvular rolled sound;

(This indiscriminate use of ' $h$ ' would certainly not be helpful in the writing of South African or Nyasaland languages, where aspiration is an important factor.)

' $B$ ' and ' $D$ ' and ' $Y$ ' represent the implosive sounds as against ' $b$ ' and ' $d$ ' and ' $y$ ' for

1 Présence africaine, déc. I957-jan. 1958, pp. 76-92. 